\title{
Taxonomic Diversity of Paradise Threadfin Polynemus paradiseus (Linnaeus, 1758) Inhabiting Southern Coastal Rivers in Bangladesh (Kepelbagaian Taksonomi Polynemus paradiseus (Linnaeus, 1758) Mendiami Selatan Pesisir Sungai di Bangladesh
}

\author{
Md. Reaz ChaKlader, MuHAmMad Abu BAKAR SidDiK* \& ASHFAQun NAHAR
}

\begin{abstract}
The study was aimed to determine the variation in taxonomic diversity of Polynemus paradiseus based on morphometric and meristic analyses of samples collected from three coastal rivers of Bangladesh (Payra, Tentulia and Kirtonkhola). A total of 105 individuals ranging at 10-20 cm in total length (TL) and 7.91-60.64 g in body weight (BW) were sampled using Been nets and Kachal and Veshal nets. Significant differences were observed in 24 out of 25 morphometric measurements and 6 out of 10 meristic counts among the populations. In morphometric measurements, the first discriminant function (DF1) was accounted for $78.6 \%$ and the second discriminant function (DF2) was accounted for $21.4 \%$ of among groups variability, explaining $100 \%$ of total among group variability. A dendrogram based on morphometric data showed that the Tentulia and Kirtankhola populations showed high degree of overlapping and these two populations were highly different from Payra river population. The canonical graph also showed that the populations of Tentulia and Kirtankhola rivers were more closely related comparing with Payra river population for isometric condition. These findings may provide useful information for the conservation and sustainable management of this important fish.
\end{abstract}

Keywords: Coastal river; meristic; morphometric; Polynemus paradiseus; taxonomic diversity

\section{ABSTRAK}

Kajian ini bertujuan untuk menentukan perubahan dalam kepelbagaian taksonomi Polynemus paradiseus berasaskan morfometrik dan analisis meristik untuk sampel yang diambil dari tiga pesisir Sungai di Bangladesh (Payra, Tentulia dan Kirtonkhola). Sejumlah 105 individu berjulat antara 10-20 cm jumlah panjang (TL) dan 7.91-60.64 g berat badan (BW) disampel menggunakan net Been serta net Kachal dan Veshal. Terdapat perbezaan ketara dalam 24 daripada 25 ukuran morfometrik dan 6 daripada 10 bilangan meristik diperhatikan antara populasi. Dalam pengukuran morfometrik, fungsi diskriminan pertama (DF1) telah menyumbang sebanyak $78.6 \%$ dan fungsi diskriminan kedua (DF2) $21.4 \%$ daripada kalangan kebolehubahan kumpulan, menjelaskan 100\% jumlah keseluruhan kebolehubahan kumpulan. Dendrogram berdasarkan data morfometrik menunjukkan bahawa populasi Tentulia dan Kirtankhola mempunyai tahap bertindih tertinggi dan sangat berbeza daripada populasi Sungai Payra. Grafberkanon juga menunjukkan bahawa populasi Sungai Tentulia dan Kirtankhola lebih berkait berbanding dengan populasi Sungai Payra dalam keadaan isometrik. Penemuan ini boleh memberikan maklumat yang berguna untuk pemuliharaan dan pengurusan mapan untuk ikan penting ini.

Kata kunci: Kepelbagaian taksonomi; meristik; morfometrik; pesisir sungai; Polynemus paradiseus

\section{INTRODUCTION}

The southern coastal rivers and estuaries of Bangladesh are characterized by high levels of commercial fish catch contributing a huge currency (USD 456 million per year) to the national economy of Bangladesh (Alam \& Thomson 2001; Belton et al. 2014; Islam 2003). Despite its vast potential, the coastal rivers are facing a continuous increase by over exploitation, apparent deterioration of the habitat, recreational activities, demographic increase and even global change consequences (Ahamed et al. 2012; Murshed-e-Jahan et al. 2014; Siddik et al. 2013). Environmental and man-made hazards (overexploitation, pesticide and aquatic pollution, spread of disease, uncontrolled introduction of exotic fishes and habitat modification due to industrialization, river-valley projects, excessive water abstraction and siltation due to clearing occurring in aquatic ecosystem) may be responsible for the alteration of taxonomic characters of fish and water parameters. These factors can cause alterations in taxonomic diversity and structure of marine communities that disrupt the production of important commercial fishery (Ahmed et al. 2013; Diego et al. 2014; Sajina et al. 2011). To ensure the sustainable capture from these resources, it is very crucial to facilitate the development of management strategies, the design of biological sampling programs and strategies for conserving the species state and biodiversity. On the contrary, poor understanding of the fish and fishery management can lead to dramatic changes in the biological attributes and productivity of a species (Ahmed et al. 2013; Sajina et al. 2011). 
Morphometrics and meristics variations have been most frequently used to differentiate stocks of a variety of fish species, despite the advent of biochemical and molecular genetics (Salini et al. 2004; Sedaghat et al. 2012; Swain $\&$ Foote 1999; Turan et al. 2006). These studies are fundamental for stock identification as well as to show stable differences in shape between groups of fish that demonstrate different growth, mortality or reproductive rates relevant for the definition of stocks (Cadrin 2000; Haniffa et al. 2014; Mohaddasi et al. 2013; Swain \& Foote 1999). As we believe, the morphological study of Polynemus paradiseus within these impacted coastal ecosystems will provide insight for other fish species as well.

Paradise threadfin fish Polynemus paradiseus is widely distributed throughout the Indian subcontinent including Bangladesh, India, Pakistan, Sri Lanka and also found in Indo-Pacific Ocean confluence of the Bay of Bengal (Afroz \& Alam 2013; Hossain 2001; Hossain et al. 2006; Hoq 2007; Nahar et al. 2014). This species has an increasingly commercial importance in southern coastal regions of Bangladesh because of its nutritional value and considered as important food item next to importance in hilsa fishery. Thus, a basic knowledge on its biology, including information on population structure could be a privilege. Few studies have been carried out in different aspects as biology and genetic variation of this species (Motomura et al. 2002; Nahar et al. 2014) but knowledge on taxonomic diversity of the $P$. paradiseus is totally unavailable. Therefore, the present study has been carried out to investigate the morphometric and meristic variation within three river populations of $P$. paradiseus inhabiting in the southern coastal regions of Bangladesh.

\section{MATERIALS AND METHODS}

\section{SAMPLING}

The threadfin fish $P$. paradiseus samples were collected from three rivers in the southern coastal region of Bangladesh. A total number of 105 threadfin fish ranging at $10-20 \mathrm{~cm}$ in total length (TL) and 7.91-60.64 $\mathrm{g}$ in body weight (BW) were sampled using Been nets and Kachal and Veshal nets $(<3 \mathrm{~mm})$ for examination. The sampling was conducted during monsoon because the water quality parameters and physiological condition of fish remain in sound condition. Once collected, the samples were preserved in $10 \%$ formaldehyde solution. The details of the collection sites, number of specimens and date of collection are presented in Table 1 and Figure 1. Water quality parameter were collected at one week intervals from different predetermined sites (Table 2).

TABLE 1 . Sources, number of specimens and date of collection of $P$. paradiseus population

\begin{tabular}{cllcc}
\hline Sample No. & Population & Collection site (District) & No. of fish & Date of collection \\
\hline 1 & Payra river & Lebukhali (Patuakhali) & 35 & June 10, 2014 \\
2 & Tentulia river & Patarhut (Bhola) & 35 & July 05, 2014 \\
3 & Kirtankhola river & Gajalia (Barisal) & 35 & July 21, 2014 \\
\hline
\end{tabular}

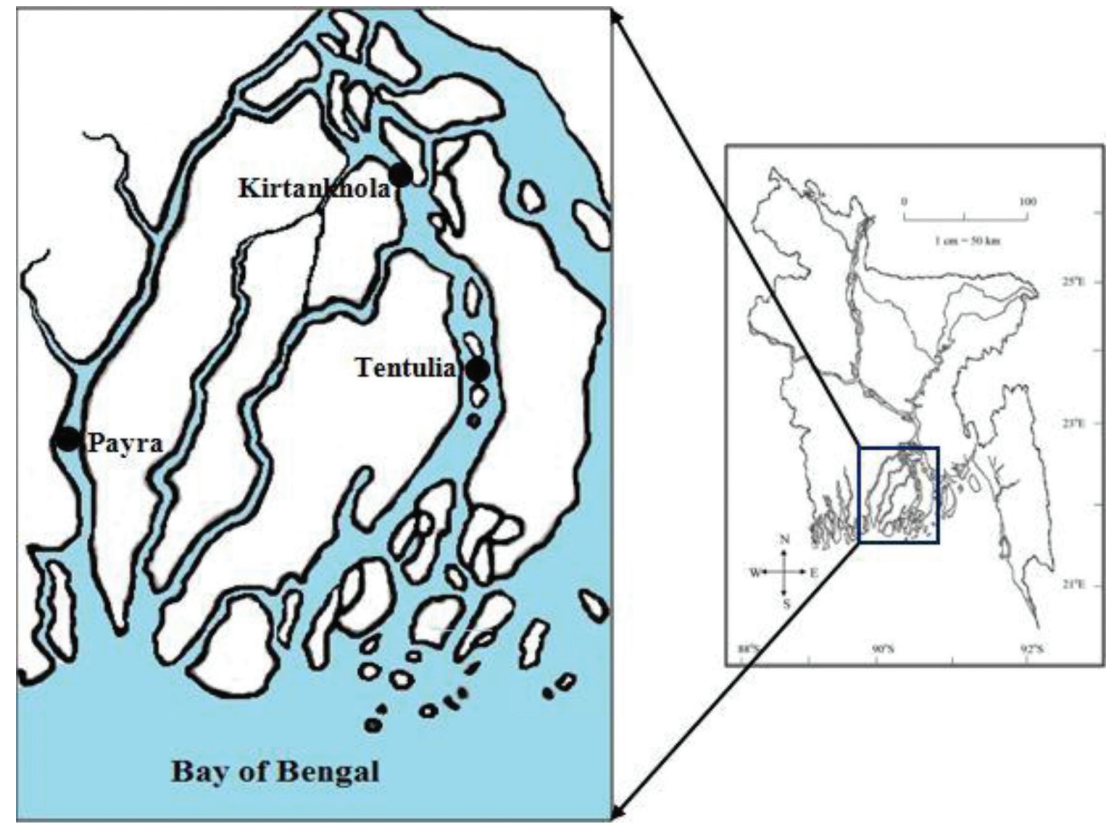

FIGURE 1. Sampling locations of P. paradiseus in three rivers, the Payra, Tentulia and Kirtankhola, located in Southern Coastal region of Bangladesh 
TABLE 2. State of aquatic environmental parameters (mean \pm SE) during the study period

\begin{tabular}{llcccc}
\hline Sources & Temperature & DO & Transparency & pH & Alkalinity (mg/L) \\
\hline Payra River & $28.58 \pm 1.34^{\mathrm{a}}$ & $8.69 \pm .40^{\mathrm{a}}$ & $25.83 \pm .55^{\mathrm{a}}$ & $7.83 \pm .16^{\mathrm{a}}$ & $116.08 \pm 2.77^{\mathrm{a}}$ \\
Tentulia River & $30.08 \pm 1.15^{\mathrm{a}}$ & $5.38 \pm .57^{\mathrm{b}}$ & $18.06 \pm .96^{\mathrm{b}}$ & $6.87 \pm .07^{\mathrm{b}}$ & $86.54 \pm 6.83^{\mathrm{b}}$ \\
Kirtankhola River & $28.99 \pm 1.54^{\mathrm{a}}$ & $5.25 \pm .26^{\mathrm{b}}$ & $16.82 \pm 2.04^{\mathrm{b}}$ & $6.99 \pm .13^{\mathrm{b}}$ & $80.24 \pm 4.36^{\mathrm{b}}$ \\
\hline
\end{tabular}

Values are mean \pm standard error. Mean values in each row bearing different superscripts are significantly different $(p<0.05)$

\section{LABORATORY WORK}

The fish were measured for 25 morphometric characters and 10 meristic counts (Figure 2). The total length of each fish was measured with digital slide calipers up to the nearest $0.1 \mathrm{~cm}$ and weighed with a digital balance up to the nearest $0.1 \mathrm{~g}$. A stereomicroscope was used for the counting of meristic features. Identification of fishes was done following Konan et al. (2014).

\section{STATISTICAL ANALYSIS}

Size effects were eliminated from the dataset prior to analysis. Variations were attributed to body shape differences and not to the relative sizes of the fish. In the present study, there were significant linear correlations among all measured characters and the TL of the fish. Therefore, it was necessary to remove size-dependent variations from all of the characters. An allometric formula given by Elliott et al. (1995) with slight modification was used to remove the size effect from the dataset:

$$
M_{\mathrm{adj}}=\mathrm{M}(\mathrm{Ls} / \mathrm{Lo})^{\mathrm{b}} \text {, }
$$

where $M$ is the original measurement; $M_{a d j}$ is the sizeadjusted measurement; Lo is the TL of the fish; and Ls is the overall mean of the TL for all fish from all samples.

Parameter b was estimated for each character from the observed data as the slope of the regression of $\log M$ on log Lo, using all fish in all groups. The results derived from the allometric method were confirmed by testing the significance of the correlation between transformed variables and standard length. To identify whether there were any statistically significant differences $(p<0.05)$ between the populations for each character, a one-way analysis of variance (ANOVA) was performed. The morphometric characters that significant were used for discriminant function analyses (DFA). As a complement to discriminant analysis, morphometric distances between the individuals of the three groups were inferred based on cluster analysis (Veasey et al. 2001). All statistical analyses were performed using SPSS v12 and SYSTAT v10.

\section{RESULTS}

\section{WATER QUALITY PARAMETERS}

The values of water quality parameters (water temperature, dissolved oxygen, transparency, $\mathrm{pH}$ and alkalinity) in different rivers are shown in Table 2 . The mean values of water temperature in different river were $28.58 \pm 1.34$, $30.08 \pm 1.15$ and $28.99 \pm 1.54$, respectively (Table 2), indicating no significant variation one to another. The DO, transparency, $\mathrm{pH}$ and alkalinity of Payra river showed significant variation $(p<0.05)$ compare to Tentulia and Kirtankhola rivers.

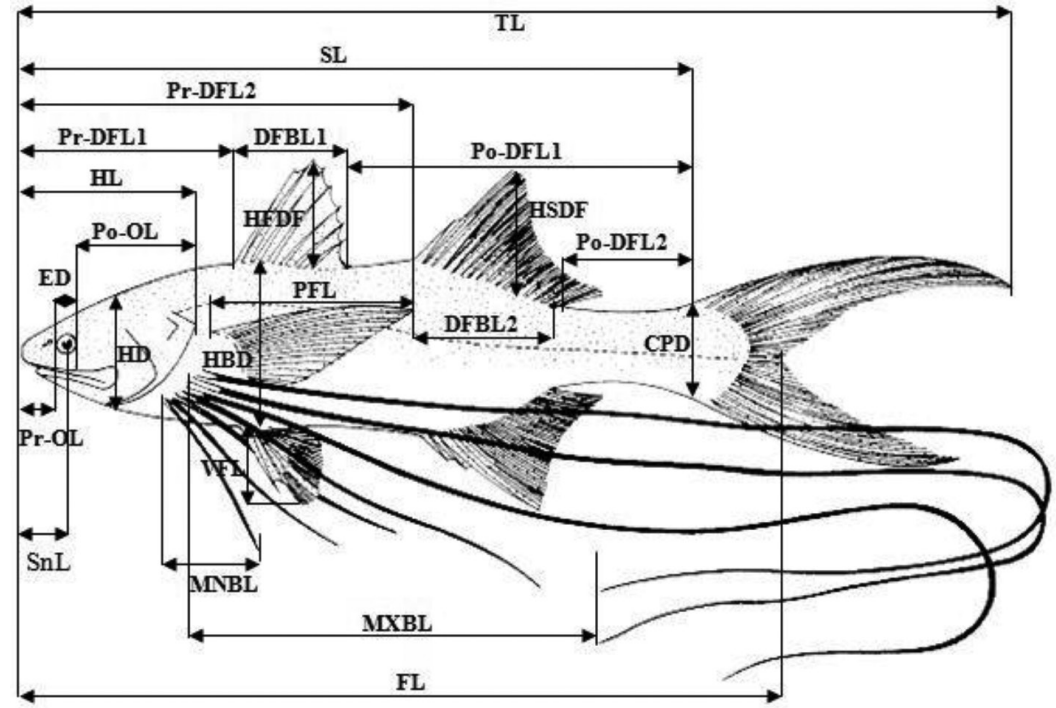

FIGURE 2. Morphometric measurement of paradise threadfin, P. paradiseus 


\section{MORPHOMETRIC CHARACTERS}

Twenty five morphometric characters were recorded for $P$. paradiseus samples from the three populations (Table $3)$. All the morphometric characters for Payra population demonstrated significantly higher average values than the other two populations (Tentulia and Kirtankhola) and Tentulia population showed lower average value than other two populations (Payra and Kirtankhola). Among the 25 morphometric characters, eye diameter (ED) for all the populations showed no significant difference from each other. The TL, FL, SL, BD, Pr-DFL1, Pr-DFL2, PFL, VFL, DFBL1 and CPD showed significant variation among all the populations. The HL, HW, Po-DFL2 and MNBL of Tentulia river populations were significantly higher than those of the Payra and Kirtankhola populations. Pr-OL, Po-OL and SnL of Kirtankhola population showed significant variation compared to the Payra and Tentulia populations.
A dendrogram based on morphometric data was drawn for the three river populations (Figure 3). The Tentulia and Kirtankhola populations were closer to each other according to the distance of Squared Euclidean Dissimilarity. The distance between Payra and Tentulia/ Kirtankhlola populations was high.

\section{MERISTIC COUNTS}

Ten meristic counts of $P$. paradiseus recorded from the three river populations are shown in Table 4 . Among them, four characters (DFR1, PFR, VFR and NB) in all the populations showed no significant difference one to another. The BSR of Tentulia populations was significantly higher than that of the Payra and Kirtankhola populations. Payra population showed significantly higher compared with Tentulia and Kirtankhola populations. But the CFR, STLL and SBLL of Tentulia and Kirtankhola populations showed significant

TABLE 3. Morphometric characters of $P$. paradiseus observed in three river populations

\begin{tabular}{|c|c|c|c|c|}
\hline \multirow{2}{*}{ Character } & \multirow{2}{*}{ Abbreviation } & \multicolumn{3}{|c|}{ Population } \\
\hline & & Payra & Tentulia & Kritonkhola \\
\hline Total length & $\mathrm{TL}$ & $17.46 \pm 0.26^{\mathrm{a}}$ & $14.96 \pm 0.02^{\mathrm{c}}$ & $16.23 \pm 0.21^{\mathrm{b}}$ \\
\hline Fork length & FL & $13.61 \pm 0.23^{\mathrm{a}}$ & $11.53 \pm 0.26^{\mathrm{c}}$ & $12.49 \pm 0.17^{b}$ \\
\hline Standard length & SL & $12.21 \pm 0.19^{a}$ & $10.19 \pm 0.15^{\mathrm{c}}$ & $11.11 \pm 0.17^{\mathrm{b}}$ \\
\hline Head length & HL & $2.67 \pm 0.05^{\mathrm{a}}$ & $2.33 \pm 0.04^{\mathrm{b}}$ & $2.62 \pm 0.05^{\mathrm{a}}$ \\
\hline Head wide & HW & $2.16 \pm 0.04^{\mathrm{a}}$ & $1.94 \pm 0.21^{\mathrm{b}}$ & $2.17 \pm 0.05^{\mathrm{a}}$ \\
\hline Body depth & $\mathrm{BD}$ & $3.22 \pm 0.06^{\mathrm{a}}$ & $2.52 \pm 0.05^{\mathrm{c}}$ & $2.73 \pm 0.06^{\mathrm{b}}$ \\
\hline Pre-Orbital length & Pr-OL & $0.62 \pm 0.03^{\mathrm{b}}$ & $0.61 \pm 0.02^{\mathrm{b}}$ & $0.69 \pm 0.02^{\mathrm{a}}$ \\
\hline Post-Orbital length & Po-OL & $0.79 \pm 0.02^{\mathrm{b}}$ & $0.81 \pm 0.02^{\mathrm{b}}$ & $0.88 \pm 0.02^{\mathrm{a}}$ \\
\hline Eye diameter & ED & $0.19 \pm 0.06^{\mathrm{a}}$ & $0.19 \pm 0.04^{\mathrm{a}}$ & $.1974 \pm 0.03^{\mathrm{a}}$ \\
\hline Snout length & SnL & $0.72 \pm 0.02^{\mathrm{b}}$ & $0.72 \pm 0.02^{\mathrm{b}}$ & $.786 \pm 0.015^{\mathrm{a}}$ \\
\hline 1st Pre-dorsal fin length & Pr-DFL1 & $3.8 \pm 0.08^{\mathrm{a}}$ & $3.09 \pm 0.06^{\mathrm{c}}$ & $3.43 \pm 0.06^{\mathrm{b}}$ \\
\hline 2nd Pre-dorsal fin length & Pr-DFL2 & $6.89 \pm 0.10^{\mathrm{a}}$ & $5.53 \pm 0.08^{\mathrm{c}}$ & $6.06 \pm 0.10^{\mathrm{b}}$ \\
\hline 1st Post-dorsal fin length & Po-DFL1 & $6.03 \pm 0.11^{\mathrm{a}}$ & $5.57 \pm 0.09^{b}$ & $5.797 \pm 0.09^{\mathrm{ab}}$ \\
\hline 2nd Post-dorsal fin length & Po-DFL2 & $2.8 \pm 0.07^{\mathrm{a}}$ & $2.49 \pm 0.04^{\mathrm{b}}$ & $2.85 \pm 0.08^{\mathrm{a}}$ \\
\hline Height of first dorsal fin & HFDF & $2.19 \pm 0.04^{\mathrm{a}}$ & $1.84 \pm 0.03^{b}$ & $1.81 \pm 0.03^{\mathrm{b}}$ \\
\hline Height of second dorsal fin & HSDF & $2.5 \pm 0.04^{\mathrm{a}}$ & $2.08 \pm 0.03^{\mathrm{b}}$ & $2.09 \pm 0.04^{\mathrm{b}}$ \\
\hline Pectoral fin length & PFL & $3.91 \pm 0.11^{\mathrm{a}}$ & $3.24 \pm 0.05^{\mathrm{c}}$ & $3.52 \pm 0.06^{\mathrm{b}}$ \\
\hline Ventral fin length & VFL & $1.9 \pm 0.04^{\mathrm{a}}$ & $1.66 \pm 0.03^{c}$ & $1.79 \pm 0.03^{\mathrm{b}}$ \\
\hline Height of anal fin & HAF & $2.25 \pm 0.04^{\mathrm{a}}$ & $1.88 \pm 0.03^{\mathrm{b}}$ & $1.83 \pm 0.03^{\mathrm{b}}$ \\
\hline 1st dorsal fin base length & DFBL1 & $2.21 \pm 0.11^{\mathrm{a}}$ & $1.59 \pm 0.05^{\mathrm{c}}$ & $1.79 \pm 0.04^{\mathrm{b}}$ \\
\hline 2nd dorsal fin base length & DFBL2 & $2.52 \pm 0.06^{\mathrm{a}}$ & $2.15 \pm .04^{\mathrm{b}}$ & $2.23 \pm 0.03^{b}$ \\
\hline Length of anal base & LAB & $2.19 \pm 0.07^{\mathrm{a}}$ & $1.85 \pm .03^{\mathrm{b}}$ & $1.88 \pm 0.02^{\mathrm{b}}$ \\
\hline Caudal peduncle depth & CPD & $1.65 \pm 1.65^{\mathrm{a}}$ & $1.33 \pm 0.03^{\mathrm{c}}$ & $1.53 \pm 0.04^{\mathrm{b}}$ \\
\hline Maximum barbell length & MXBL & $24.76 \pm 0.94^{\mathrm{a}}$ & $18.64 \pm 0.54^{\mathrm{b}}$ & $20.15 \pm 0.50^{\mathrm{b}}$ \\
\hline Minimum barbell length & MNBL & $2.99 \pm 0.11^{\mathrm{a}}$ & $2.49 \pm 0.056^{\mathrm{b}}$ & $2.83 \pm 0.075^{\mathrm{a}}$ \\
\hline
\end{tabular}

Values are mean \pm standard error. Mean values in each row bearing different superscripts are significantly different $(p<0.05)$

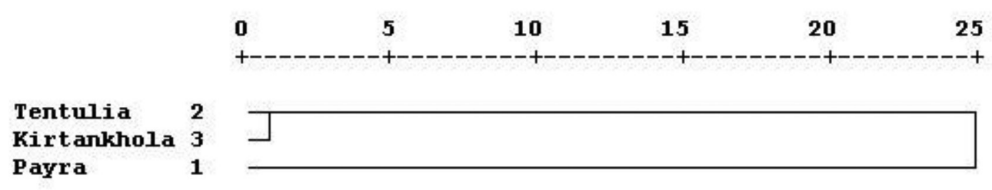

FIGURE 3. Dendrogram based on morphometric characters of $P$. paradiseus 
variation than that of the Payra population. The SALL of Kirtankhola population was significantly higher compared to Tentulia population, but not with Payra population.

Discriminant function analysis produced two discriminant functions (DF1 and DF2) for morphometric measurements. The DF1 was accounted for $78.6 \%$ and the DF2 was $21.4 \%$ among group variability, explaining $100 \%$ of total among group variability. All the samples were slightly different from one another in the discriminant space and virtually with some overlapping (Figure 4). This suggests that there was some intermingling among populations and the populations were not separated. The diagram showed that the Kirtankhola population was more dispersed in their morphological parameters than the Payra and Tentulia populations. The Payra population was more or less uniformly patterned in their morphological parameters. The Tentulia population contained somewhat compact in form.

The canonical graph of three river populations was sequentially distributed in cluster form around their centroid value. This suggests that morphological growth trend of them more or less similar. The Tentulia and Kirtankhola populations are more closely related comparing to the Payra population for isometric condition.

\section{DISCUSSION}

In the present study highly significant morphological variations has been observed among the Payra, Tentulia and Kirtankhola populations. The mean value for all attributes of Payra population was higher compared to Tentulia and Kirtankhola populations, indicating the condition of Payra river was better than other two rivers. Almost all the morphometric characters (TL, FL, STL, HL, HW, BD, Pr-OL, Po-OL, SnL, Pr-DFL1, Pr-DFL2, Po-DFL1, Po-DFL1, Po-DFL2, HFDF, HSDF, PFL, VFL, HAF, DFBL1, DFBL2, $\mathrm{LAB}, \mathrm{CPD}, \mathrm{MXBL}$ and MNBL) showed significant variation whereas only ED was not significant among each other (Table 3). These significant variations might be related to the geography, ecology, human activities and genetic

TABLE 4. Meristic counts of $P$. paradiseus observed in three river populations

\begin{tabular}{lcccc}
\hline Sample & Abbrevia-tions & Payra Mean \pm SE & Tentulia Mean \pm SE & Kritonkhola Mean \pm SE \\
\hline No.branchiostegal ray & BSR & $7.00 \pm 0.00^{\mathrm{a}}$ & $6.86 \pm 0.083^{\mathrm{b}}$ & $7.00 \pm 0.00^{\mathrm{a}}$ \\
1st dorsal fin ray & DFR1 & $6.97 \pm 0.03^{\mathrm{a}}$ & $7.03 \pm 0.029^{\mathrm{a}}$ & $7.00 \pm 0.00^{\mathrm{a}}$ \\
2nd dorsal fin ray & DFR2 & $15.20 \pm 0.20^{\mathrm{b}}$ & $15.80 \pm 0.099^{\mathrm{a}}$ & $15.80 \pm 0.02^{\mathrm{a}}$ \\
Pectoral fin ray & PFR & $15.83 \pm 0.14^{\mathrm{a}}$ & $15.91 \pm 0.048^{\mathrm{a}}$ & $15.91 \pm 0.06^{\mathrm{a}}$ \\
Ventral fin ray & VFR & $5.06 \pm 0.06^{\mathrm{a}}$ & $5.00 \pm 0.000^{\mathrm{a}}$ & $5.00 \pm 0.00^{\mathrm{a}}$ \\
Caudal fin ray & CFR & $18.80 \pm 0.15^{\mathrm{a}}$ & $18.29 \pm 0.088^{\mathrm{b}}$ & $18.00 \pm 0.04^{\mathrm{b}}$ \\
Scale through the lateral line & STLL & $66.49 \pm 0.34^{\mathrm{a}}$ & $64.43 \pm 0.379^{\mathrm{b}}$ & $64.37 \pm 0.21^{\mathrm{b}}$ \\
Scale above the lateral line & SALL & $7.71 \pm 0.14^{\mathrm{ab}}$ & $7.43 \pm 0.094^{\mathrm{b}}$ & $7.86 \pm 0.06^{\mathrm{a}}$ \\
Scale below the lateral line & SBLL & $15.97 \pm 0.21^{\mathrm{a}}$ & $13.89 \pm 0.224^{\mathrm{b}}$ & $13.86 \pm 0.15^{\mathrm{b}}$ \\
No. barbell & NB & $7.00 \pm 0.00^{\mathrm{a}}$ & $7.00 \pm 0.000^{\mathrm{a}}$ & $7.00 \pm 0.00^{\mathrm{a}}$ \\
\hline
\end{tabular}

Values are mean \pm standard error. Mean values in each row bearing different superscripts are significantly different $(p<0.05)$

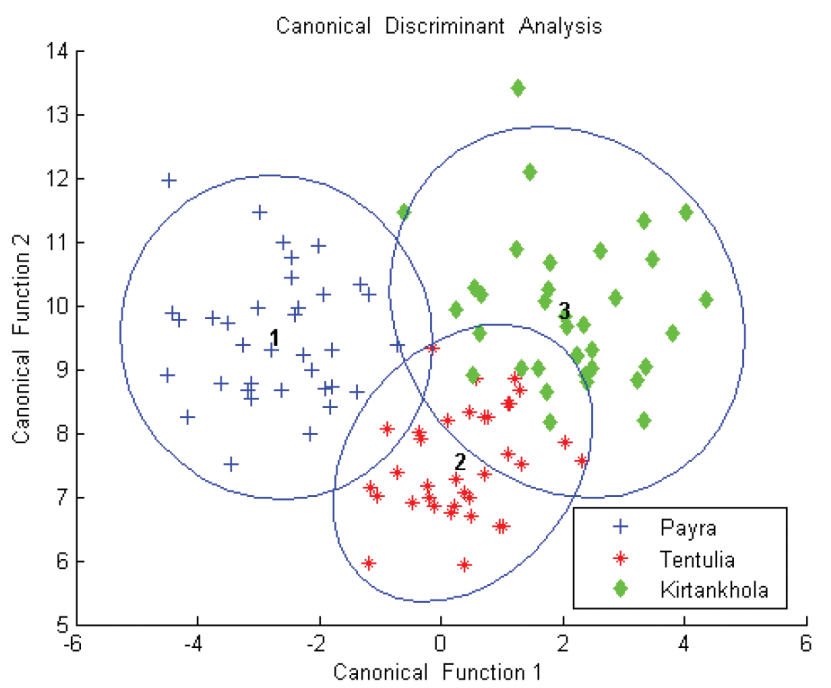

FIGURE 4. Coordinate plot of two discriminant functions based on morphometric measurement of $P$. paradiseus from three river populations. 1: Payra population, 2: Tentulia population and 3: Kirtankhola population 
diversity of the populations. A similar study was performed on endangered carp Labeo calbasu from two stocks of isolated rivers and a hatchery population where significant variation was observed in all the morphometric characters (Hossain et al. 2010). Several studies has also reported on morphometric measurements and meristic counts on different fishes and variations due to geography, ecology and human activities were observed (Cabral et al. 2003; Khayyami et al.2014; Pinheiro et al. 2005). Morphometric differences are expected among stocks collected from separated locations as they might have originated from different ancestors (Hossain et al. 2010) and might be due to their adaptation capacity. Fish are very sensitive to environmental changes (such as food abundance and temperature) and they have ability to adapt themselves by changing necessary morphometric (Allendorf \& Phelps 1988; Mir et al. 2013; Swain et al. 1991; Wimberger 1992). In general, fish demonstrate greater variances in morphological traits both within and between populations than any other vertebrates and they are more susceptible to environmentally induced morphological variations (Coad 1980; Scheimer 1993; Wimberger 1992).

Water quality parameters were in good condition in Payra River compared to the other two rivers, while the water parameters were homogenous in Tentulia and Kirtankhola Rivers. Observed morphometric and meristic differences in this investigation were probably influenced by environmental parameters. The present findings agree with those of Schreck and Moyle (1990) and Kurata (1975) who reported that the meristic counts of fishes were affected by environmental factors (such as water temperature, $\mathrm{pH}$ ) in fresh water.

The dendrogram contained two clusters - the Tentulia and Kirtankhola stocks in one cluster and the Payra stock in another (Figure 3). The difference between the Payra stock and the other two stocks might have been due to environmental as well as genetic variations. The Tentulia and Kirtankhola stocks are more or less similar and this might be consequence of migratory behavior of the fish from Tentulia to Kirtankhola Rivers and vice-versa. Paradise threadfin fish inhibits in the estuaries and Bengal Bay, Bangladesh (Rahman 2005) and enters freshwater during spawning time (Talwar \& Jhingran 1991). Since the Tentulia River is located in the estuarine region and has direct connection with the Kirtankhola River (Figure 1), it may contribute to the similarity in taxonomic characters. A relationship was found among the three stocks according to the two discriminant functions (DF1 and DF2) from the morphometric measurement of three populations of $P$. paradiseus. In DF1, the Tentulia and Kirtankhola populations displayed some similar characteristics. The Tentulia and Kirtankhola populations were broadly overlapped, while the Payra population clearly differed the former two based on DF2.

The meristic counts of the three populations varied from 6 to 8 for branchiostegal rays, 5 to 8 for dorsal fin rays, 14 to 18 for pectoral fin rays, 4 to 6 for ventral fin rays and 17 to 20 for caudal fin rays. The number of barbels for all the samples was 7 . This result was adapted with the taxonomic formula (Rahman 2005; Talwar \& Jhingran1991). The mean number of BSR, DFR2, CFR, STLL, SALL and SBLL were significantly different among all the populations but no significant correlations were observed between meristic counts of $P$. paradiseus on DFR1, PFR, VFR and NB. A similar result was observed in the study of endangered carp Labeo calbasu where difference in meristic counts was recorded for L. calbasu from two stocks of isolated rivers and a hatchery (Hossain et al. 2010).

\section{ACKNOWLEDGEMENTS}

We sincerely thank Professor Dr. Hironori Ando, Sado Marine Biological Station, Niigata University, Japan and Professor Dr. Sultan Mahmud of Patuakhali Science and Technology University for their valuable comments in updating the manuscript.

\section{CONCLUSION}

The output of this study will provide useful baseline information of $P$. paradiseus populations for further studies. In both aquaculture and open-water management, it is essential to know the population structure, the habitats in which they inhabit and the impacts of external factors on their well-being. The morphometric and meristic diversities observed in this study will help in monitoring the species status in the southern coastal regions of Bangladesh as a bid to take appropriate management measures for the populations in future.

\section{REFERENCES}

Afroz, T. \& Alam, S. 2013. Sustainable shrimp farming in Bangladesh: A quest for an integrated coastal zone management. Ocean \& Coastal Management 71: 275-283.

Ahamed, F., Hossain, M.Y., Fulanda, B., Ahmed, Z.F. \& Ohtomi, J. 2012. Indiscriminate exploitation of wild prawn post-larvae in the coastal region of Bangladesh: A threat to the fisheries resources, community livelihoods and biodiversity. Ocean \& Coastal Management 66: 56-62.

Ahmed, N., Occhipinti-Ambrogi, A., James, F. \& Muir, R. 2013. The impact of climate change on prawn post-larvae fishing in coastal Bangladesh: Socioeconomic and ecological perspectives. Marine Policy 39: 224-233.

Alam, M.F. \& Thomson, K.J. 2001. Current constraints and future possibilities for Bangladesh fisheries. Food Policy 26(3): 297-313.

Allendorf, F.W. \& Phelps, S.R. 1988. Loss of genetic variation in hatchery stock of cutthroat trout. Trans. Am. Fish Soc. 109: 537-543.

Belton, B., Asseldonk, I.J.M. \& Thilsted, S.H. 2014. Faltering fisheries and ascendant aquaculture: Implications for food and nutrition security in Bangladesh. Food Policy 44: 77-87.

Cabral, H.N., Marques, J.F., Rego, A.L., Catarino, A.I., Figueiredo, J. \& Garcia, J. 2003. Genetic and morphological variation of Synaptura lusitanica Capello, 1868, along the Portuguese coast. Journal of Sea Research 50(2-3): 167-175. 
Cadrin, S.X. 2000. Advances in morphometric identification of fishery stocks. Reviews in Fish Biology and Fisheries 10(1): 91-112.

Coad, B.W. 1980. Environmental change and its impact on the freshwater fishes of Iran. Biological Conservation 19: 51-80.

Diego, J.V., Emelio, B.G., Eleonora, V.R. \& Abril, P.K. 2014. Variation in taxonomic diversity of the fish assemblage associated with soft bottoms in San Ignacio Lagoon, Baja California Sur, Mexico. Journal of Biodiversity, Bioprospecting and Development 1(2): 1000118.

Elliott, N.G., Haskard, K. \& Koslow, J.A. 1995. Morphometric analysis of orange roughly (Hoplostethus atlanticus) of the continental slope of Southern Australia. Journal of Fish Biology 46: 202-220.

Haniffa, M.A.,Abiya, J.S., Milton, J., Ramesh, K., Bhat, A.A. \& Chelliah,A. 2014. Morphometric, meristic and ISSR marker systems for species identification and evolutionary analysis in five Indian Channids. Biochemical Systematics and Ecology 55: $131-136$

Hoq, M.E. 2007. An analysis of fisheries exploitation and management practices in Sundarbans mangrove ecosystem, Bangladesh. Ocean \& Coastal Management 50(5-6): 411427.

Hossain, M.A.R., Nahiduzzaman, M., Saha, D., Khanam, U.H. \& Alam, M.S. 2010. Landmark-based morphometric and meristic variations of the endangered carp, kalibaus Labeo calbasu, from stocks of two isolated rivers, the Jamuna and Halda, and a hatchery. Zoological Studies 49(4): 556-563.

Hossain, M.M., Islam, M.A., Ridgway, S. \& Matsuishi, T. 2006. Management of inland open water fisheries resources of Bangladesh: Issues and options. Fisheries Research 77(3): 275-284.

Hossain, M.S. 2001. Biological aspects of the coastal and marine environment of Bangladesh. Ocean \& Coastal Management 44(3-4): 261-282.

Islam, M.S. 2003. Perspectives of the coastal and marine fisheries of the Bay of Bengal, Bangladesh. Ocean \& Coastal Management 46: 763-796.

Khayyami, H., Movahedinia, A., Zolgharnein, H. \& Salamat, N. 2014. Morphological variability of Liza aurata (Risso, 1810), along the southern Caspian Sea. The Journal of Basic \& Applied Zoology 67(3): 100-107.

Konan, K.T., Adepo-Gourene, A.B., Konan, K.M. \& Gourene, G. 2014. Morphological differentiation among species of the genus Mugil Linnaeus, 1758 (Mugilidae) from Cote d'Ivoire. Turkish Journal of Zoology 38: 273-284.

Kurata, H., 1975. Environmental conditions. Feeding and Growth of Larval Fish. Koseishakoseikaku, Tokyo: The Japanese Society of Fisheries. pp. 45-46.

Mir, F.A., Mir, J.I. \& Chandra, S. 2013. Phenotypic variation in the nnow trout Schizothorax richardsonii (Gray, 1832) (Actinopterygii: Cypriniformes: Cyprinidae) from the Indian Himalayas. Contributions to Zoology 82(3): 115-122.

Mohaddasi, M., Shabanipour, N. \& Abdolmaleki, S. 2013. Morphometric variation among four populations of Shemaya (Alburnus chalcoides) in the south of Caspian Sea using truss network. The Journal of Basic \& Applied Zoology 66(2): 87-92.

Motomura, H., Kullander, S.O., Yoshino T. \& Iwatsuki, Y. 2002. Review of seven-spined Polynemus species (Perciformes: Polynemidae) with designation of a neotype for Polynemus paradiseus Linnaeus, 1758. Ichthyological Research 49(4): 307-317.
Murshed-e-Jahan, K., Belton, B. \& Viswanathan, K.K. 2014. Communication strategies for managing coastal fisheries conflicts in Bangladesh. Ocean \& Coastal Management 92: 65-73.

Nahar, A., Siddik, M.A.B., Alam, M.A., Ahsan, M.E. \& Chaklader, M.R. 2014. Population genetic structure of paradise threadfin Polynemus paradiseus (Linnaeus, 1758) revealed by allozyme marker. World Journal of Zoology 9(4): 260-266.

Pinheiro, A., Teixeira, C.M., Rego, A.L., Marques, J.F., Henrique, N. \& Cabral. 2005. Genetic and morphological variation of Solea lascaris (Risso, 1810) along the Portuguese coast. Fisheries Research 73(1-2): 67-78.

Rahman,A.K.A. 2005. Freshwater Fishes of Bangladesh. 2nd ed. Zoological Society of Bangladesh, Department of Zoology, University of Dhaka. p. 293.

Sajina, A.M., Chakraborty, Jaiswar, S.K., Pazhayamadam,A.K. \& Sudheesan, D.G. 2011. Stock structure analysis of Megalaspis cordyla (Linnaeus, 1758) along the Indian coast based on truss network analysis. Fisheries Research 108(1): 100-105.

Salini, J.P., Milton, D.A., Rahman, M.J. \& Hussain, M.G. 2004 Allozyme and morphological variation throughout the geographic range of the tropical shad, hilsa Tenualosa ilisha. Fisheries Research 66(1): 53-69.

Scheimer, S.M. 1993. Genetics and evolution of phenotypic plasticity. Annual Review of Ecology and Systematics 24: 35-68

Schreck, C.B. \& Moyle, P.B. 1990. Methods for Fish Biology. Bethesda: American Fisheries Society. p. 684.

Sedaghat, S., Hosseini, S.A. \& Abdol, A.F. 2012. Morphometric and meristic characteristics studies of Loach, Paracobitis malapterurus (Valenciennes, 1846) in the Zarrin-Gol River, East of the Elburz Mountains (Northern Iran). AmericanEurasian Journal of Agriculture \& Environmental Science 12(10): 1282-1287.

Siddik, M.A.B., Nahar, A., Ahamed, F., Masood, Z. \& Hossain, M.Y. 2013. Conservation of critically endangered olive barb Puntius sarana (Hamilton, 1822) through artificial propagation. Our Nature 11(2): 96-104.

Swain, D.P. \& Foote, C.J. 1999. Stocks and chameleons: The use of phenotypic variation in stock identification. Fisheries Research 43: 1123-1128.

Swain, D.P., Ridell, B.E. \& Murray, C.B. 1991. Morphological differences between hatchery and wild populations of coho salmon (Oncorhynchus kisutch): Environmental versus genetic origin. Canadian Journal of Fish and Aquatic Sciences 48: 1783-1791.

Talwar, P.K. \& Jhingran, A.G. 1991. Inland Fishes of India and Adjacent Countries. Vol. 2. New Delhi-Calcutta: Oxford \& IBH Publishing Co. Pvt. Ltd. pp. 911-912.

Turan, C., Oral, M., Öztürk, B. \& Düzgüneş, E. 2006. Morphometric and meristic variation between stocks of bluefish (Pomatomus saltatrix) in the Black, Marmara, Aegean and northeastern Mediterranean Seas. Fisheries Research 79(1-2): 139-147.

Veasey, E.A., Schammass, E.A., Vencovsky, R., Martins, P.S.\& Bandel, G. 2001. Germplasm characterization of Sesbania accessions based on multivariate analyses. Genetic Resources and Crop Evolution 48: 79-90.

Wimberger, P.H. 1992. Plasticity of fish body shape - the effects of diet, development, family and age in two species of Geophagus (Pisces: Cichlidae). Biological Journal of the Linnean Society 45: 197-218. 
Md. Reaz Chaklader \& Muhammad Abu Bakar Siddik* Department of Fisheries Biology and Genetics

Patuakhali Science and Technology University

Patuakhali - 8602

Bangladesh

Muhammad Abu Bakar Siddik*

Curtin Aquatic Research Laboratory

Curtin University of Technology, WA 6102

Australia

Ashfaqun Nahar

Department of Marine Fisheries and Oceanography

Patuakhali Science and Technology University

Patuakhali - 8602

Bangladesh
*Corresponding author; email: m.siddik@student.curtin.edu.au

Received: 19 November 2014

Accepted: 6 May 2015 